\title{
Measuring Poverty Reduction and Targeting Performance Under Multiple Government Programs*
}

\author{
Paul Makdissi ${ }^{\dagger} \quad$ Quentin Wodon ${ }^{\ddagger}$
}

August 2001

\begin{abstract}
The evaluation of the poverty impact and targeting performance of a given social program may depend on how other programs are treated in the analysis. Using well-known results from cooperative game theory, this paper proposes an empirically simple yet theoretically sound method for allocating between various programs the overall poverty reduction obtained from a set of programs, and for assessing the targeting performance of each program.
\end{abstract}

Keywords: Poverty, targeting, social programs, Chile, Latin America JEL Codes: H53, I38

*This paper was funded by a grant from the World Bank's Research Support Budget. The opinions expressed here are those of the authors and need not represent those of the World Bank, its Executive Directors, or the countries they represent. The first author has also benefitted from the support of the Bureau de la recherche of Université de Sherbrooke.

† Département d'économique and CEREF, Université de Sherbrooke, 2550, boulevard de l'Université, Sherbrooke, Québec, Canada, J1K 2R1; Email: paul.makdissi@courrier.usherb.ca.

$\ddagger$ LCSPR, World Bank, 1818 H Street, NW, Washington, DC 20433, USA, Email: qwodon@worldbank.org. 


\section{Introduction}

When evaluating a given social program in a setting where other poverty-oriented programs are implemented at the same time, an analyst may face a potentially difficult problem: the estimates of the poverty reduction impact and targeting performance of the program under review may depend on how the other programs are treated in the analysis. To illustrate the difficulty, consider a country with two indentical social programs. Each program reaches all poor households, and it provides each poor household with a transfer which brings the household exactly to the level of the poverty line, so that no households are poor after the implementation of the any one of the two programs. The poverty impact of each program is measured by comparing a given measure of poverty, say from the FGT class (Foster, Greer and Thorbecke 1984), with and without the program. If the income aggregate used to estimate the poverty impact of each program includes the transfer from the other program, none of the two programs has any impact on poverty, although both manage individually to eradicate poverty when the other program is not taken into account in the income aggregate.

The same type of issues occur with measures of targeting performance. In the literature on targeting (e.g., Baker and Grosh 1994; Cornia and Stewart 1995; Morris et al. 1999, Wodon 1997), one typically says that an error of inclusion is observed when a household receives benefits although it is not part of the program's target population (for example, the poor or the extreme poor). An error of exclusion is observed when a household which is part of the program's target population does not receive benefits. Let's focus on the errors of inclusion. If the income aggregate used to estimate the targeting performance of each program includes the transfer from the other program, we observe a maximum number of 
errors of inclusion since all program beneficiaries are non poor thanks to the other program. By contrast, if the income aggregate does not include the other program, we do not observe any error of inclusion.

In this paper, following previous work by Makdissi and Therrien (2001), we propose an empirically simple yet theoretically sound procedure to measure the poverty reduction impact of programs and their targeting performance when other programs are implemented at the same time. Our procedure is based on an application to poverty measurement and targeting analysis of a rule developed in the context of cooperative game theory by Shapley (1953). On the basis of three straightforward axioms, Shapley's rule proposes a unique solution for the allocation of the total surplus obtained in a game from the contribution of each player to the game. We suggest to apply the same rule for allocating between various programs the total poverty reduction impact obtained from multiple programs, and for assessing the targeting performance of each program. Section 2 presents our methodology and section 3 provides an empirical application using recent household survey data from Chile.

\section{Methodology}

There are $n$ public programs to analyze. We denote by $G$ the set of those programs. Each program is denoted by $g_{i}, i=1,2, \ldots, n$. We are interested in assessing the impact of the programs on poverty and extreme poverty, and in evaluating their targeting performance. The population consists of $A$ households with per capita (or adult equivalent) income $y_{a}$, $a=1,2, \ldots, A$. The households are sorted by their level of income such that $y_{a-1} \leq y_{a} \leq y_{a+1}$ for $a=2,3, \ldots ., a-1$. The poverty line is $z$ with $y_{q}<z \leq y_{q+1}$. We take household weights into account in all empirical estimations.

To measure poverty, we use the first three measures of the FGT (Foster, Greer, and 
Thorbecke, 1984) class. Each measure is computed with both extreme and moderate poverty lines. The first measure is the headcount index of poverty, which is simply the percentage of the population living in households with per capita income below the poverty line. This is denoted by $P^{o}$. The second measure, which captures the depth of poverty, is the poverty gap index $P^{1}$. It estimates the average distance separating the poor from the poverty line as a proportion of that line (the mean is taken over the whole sample with a zero distance allocated to the households who are not poor.) The third measure, which captures the severity of poverty, is the squared poverty gap index $P^{2}$. It takes into account not only the distance separating the poor from the poverty line, but also the inequality among the poor. The three poverty measures are obtained for values of $\alpha$ equal to 0,1 , and 2 in:

$$
P^{\alpha}=\frac{1}{A} \sum_{a=1}^{q}\left(\frac{z-y_{a}}{z}\right)^{\alpha} .
$$

To assess the impact of each program on poverty, we compute the three poverty measures with and without the income transfered by the program. The difficulty is that the reduction in poverty due to each program depends on whether the income transfered by the other programs is taken into account in the income aggregate. Assume for example that we have three programs, and that the first two manage to eradicate poverty. Then, if the income aggregate used to analyze the impact of the third program includes the first two, the third program has no impact at all on poverty. By contrast, if the income aggregate does not include the first two programs, then the third program will generate at least some level of poverty reduction if it does reach some of the poor. What we are looking for is a measure of the poverty reduction impact of each program, denoted by $\Delta^{\alpha}\left(\left\{g_{i}\right\}\right)$, which is able to take into account the fact that the impact of each program depends on whether the income aggregate before the implementation of the specific program under review includes some or all of the other programs. To derive our measure of the poverty reduction impact of each 
program, we rely on three axioms.

Axiom 1 Focus: $\Delta^{\alpha}\left(\left\{g_{i}\right\}\right)=0$ if policy $i$ has no impact on the income of at least one poor agent.

The focus axiom states that if a program does not benefit at least one poor person, its impact on poverty is zero.

Axiom 2 Additivity: $\forall g_{i}, g_{j}, \Delta^{\alpha}\left(S \cup\left\{g_{i}, g_{j}\right\}\right)=\Delta^{\alpha}\left(S \cup\left\{g_{i}\right\}\right)+\Delta^{\alpha}\left(S \cup\left\{g_{j}\right\}\right), \forall S \subseteq$ $G \backslash\left\{g_{i}, g_{j}\right\}$

In the additivity axiom, $\Delta^{\alpha}(S)$ denotes the reduction of poverty obtained with a set of programs $S$. We are interested in assessing the poverty reduction obtained from two additional programs not included in $S$, namely $g_{i}$ and $g_{j}$. When both programs are added to the programs already included in $S$, the set of programs under implementation is $S \cup\left\{g_{i}, g_{j}\right\}$. The axiom states that the additional poverty reduction from the implementation of the two new programs is the sum of the poverty reduction obtained from each. This property corresponds to the additive nature of the FGT poverty measures.

Axiom 3 Equal treatment of equivalent policies (P): If $P^{\alpha}\left(S \cup\left\{g_{i}\right\}\right)=P^{\alpha}\left(S \cup\left\{g_{j}\right\}\right)$ $\forall S \subseteq G \backslash\left\{g_{i}, g_{j}\right\}$ then $\Delta^{\alpha}\left(\left\{g_{i}\right\}\right)=\Delta^{\alpha}\left(\left\{g_{j}\right\}\right)$.

The equal treatment axiom states that if the impact of two programs is always the same independently of which other programs have already been taken into account in the income aggregate, then the two programs have the same poverty reduction impact.

In the context of cooperative game theory, Shapley (1953) demontrated that one and only one rule for allocating the total surplus obtained from the contribution of each player 
respected these three axioms ${ }^{1}$. Shapley's rule consists in computing the contribution of each player for every potential ordering of the other players, and in taking as the allocation rule for each player the average of all his contributions under all possible scenarios. Makdissi and Therrien (2001) used Shapley's theorem to show that in the context of poverty measurement, one and only one measure of the impact on poverty of the various programs satisfies the above axioms.

Proposition 4 The only measure of poverty reduction which satisfies Axioms 1, 2, and 3, which we will refer to as the Shapley poverty reduction impact of program $g_{i}$, is:

$$
\Delta^{\alpha}\left(\left\{g_{i}\right\}\right)=\sum_{s=0}^{n-1} \frac{s !(n-s-1) !}{n !} \sum_{\beta_{-i}(s)}\left[P^{\alpha}(S)-P^{\alpha}\left(S \cup\left\{g_{i}\right\}\right)\right],
$$

where $\beta_{-i}(s)=\{S: i \notin S \wedge|S|=s\}$.

The proposition 4 states that in order to respect our three axioms, the impact of program $g_{i}$ on poverty, $\Delta^{\alpha}\left(\left\{g_{i}\right\}\right)$, must be the average of the poverty reduction obtained with $g_{i}$ for all possible permutations of the various programs. Using equation (2) eases a bit the computation of the average by allowing the analyst to compute only one time the poverty reduction for all permutation in which a given policy $g_{i}$ has the same rank and follows the same other policies, whatever the order of those other policies.

It is an empirical matter whether there will be a difference between the Shapley poverty reduction impact of program $g_{i}$ and another measure of impact based, say, on only one of the possible permutations of all the programs. Yet, we can extend the results of Makdissi and Therrien (2001) by showing that if the programs under consideration have little overlap because they are directed towards different demographic subgroups, the difference in estimates will be small. By contrast, if the programs overlap because they are directed toward

1 Mathematicaly, our focus axiom is equivalent to Shapley's dummy player axiom. Since our two other axioms are the same as those stated by Shapley, we can use his theorem and apply it directly to our own context. 
the same demographic subgoups (or because they benefit most of the poor, whatever their socio-economic characteristics), then the difference in estimates may be substantial.

To illustrate this argument, consider a partition of the total population $A$ into $A_{1}, A_{2}$, $A_{3}$ and suppose that we have three programs $g_{1}, g_{2}$ and $g_{3}$ which are directed only towards the members of $A_{1}, A_{2}$ and $A_{3}$ respectively. This is thus a case when there is no overlap at all between the various programs. We denote by $P_{i}^{\alpha}(S)$ the poverty rate of demographic group $A_{i}$ when the set $S$ of programs is implemented. The Shapley poverty reduction impact of the first program is:

$$
\begin{aligned}
& \Delta^{\alpha}\left(\left\{g_{1}\right\}\right)=\sum_{s=0}^{2} \frac{s !(3-s-1) !}{3 !} \sum_{\beta_{-i}(s)}\left[P^{\alpha}(S)-P^{\alpha}\left(S \cup\left\{g_{i}\right\}\right)\right], \\
& \Delta^{\alpha}\left(\left\{g_{1}\right\}\right)= \frac{1}{3}\left[P^{\alpha}(\phi)-P^{\alpha}\left(\left\{g_{1}\right\}\right)\right]+\frac{1}{6}\left[P^{\alpha}\left(\left\{g_{2}\right\}\right)-P^{\alpha}\left(\left\{g_{1}, g_{2}\right\}\right)\right] \\
&+\frac{1}{6}\left[P^{\alpha}\left(\left\{g_{3}\right\}\right)-P^{\alpha}\left(\left\{g_{1}, g_{3}\right\}\right)\right]+\frac{1}{3}\left[P^{\alpha}\left(\left\{g_{2}, g_{3}\right\}\right)-P^{\alpha}\left(\left\{g_{1}, g_{2}, g_{3}\right\}\right)\right],
\end{aligned}
$$

where $\phi$ is the empty set (i.e., the income aggregate used to analyze the impact of $g_{1}$ does not include $g_{2}$ and $g_{3}$ ). Using the additive property of $P^{\alpha}$, we know that:

$$
P^{\alpha}(S)=\sum_{i=1}^{3} \theta_{i} P_{i}^{\alpha}(S),
$$

where $\theta_{i}=A_{i} / A$ represents the share of the total population which belongs to the demographic group $A_{i}$. Keeping in mind that only policy $g_{i}$ has an impact on the households in demographic group $A_{i}$, we can use equation (5) to rewrite equation (4) as 


$$
\begin{aligned}
\Delta^{\alpha}\left(\left\{g_{1}\right\}\right)= & \frac{1}{3}\left[\theta_{1} P_{1}^{\alpha}(\phi)+\theta_{2} P_{2}^{\alpha}(\phi)+\theta_{3} P_{3}^{\alpha}(\phi)\right. \\
& \left.-\theta_{1} P_{1}^{\alpha}\left(\left\{g_{1}\right\}\right)-\theta_{2} P_{2}^{\alpha}(\phi)-\theta_{3} P_{3}^{\alpha}(\phi)\right] \\
& +\frac{1}{6}\left[\theta_{1} P_{1}^{\alpha}(\phi)+\theta_{2} P_{2}^{\alpha}\left(\left\{g_{2}\right\}\right)+\theta_{3} P_{3}^{\alpha}(\phi)\right. \\
& \left.-\theta_{1} P_{1}^{\alpha}\left(\left\{g_{1}\right\}\right)-\theta_{2} P_{2}^{\alpha}\left(\left\{g_{2}\right\}\right)-\theta_{3} P_{3}^{\alpha}(\phi)\right] \\
& +\frac{1}{6}\left[\theta_{1} P_{1}^{\alpha}(\phi)+\theta_{2} P_{2}^{\alpha}(\phi)+\theta_{3} P_{3}^{\alpha}\left(\left\{g_{3}\right\}\right)\right. \\
& \left.-\theta_{1} P_{1}^{\alpha}\left(\left\{g_{1}\right\}\right)-\theta_{2} P_{2}^{\alpha}(\phi)-\theta_{3} P_{3}^{\alpha}\left(\left\{g_{3}\right\}\right)\right] \\
& +\frac{1}{3}\left[\theta_{1} P_{1}^{\alpha}(\phi)+\theta_{2} P_{2}^{\alpha}\left(\left\{g_{2}\right\}\right)+\theta_{3} P_{3}^{\alpha}\left(\left\{g_{3}\right\}\right)\right. \\
& \left.-\theta_{1} P_{1}^{\alpha}\left(\left\{g_{1}\right\}\right)-\theta_{2} P_{2}^{\alpha}\left(\left\{g_{2}\right\}\right)-\theta_{3} P_{3}^{\alpha}\left(\left\{g_{3}\right\}\right)\right],
\end{aligned}
$$

which simplifies to

$$
\Delta^{\alpha}\left(\left\{g_{1}\right\}\right)=\frac{1}{3}\left[\theta_{1} P_{1}^{\alpha}(\phi)-\theta_{1} P_{1}^{\alpha}\left(\left\{g_{1}\right\}\right)\right] .
$$

Using a similar methodology, we have

$$
\Delta^{\alpha}\left(\left\{g_{2}\right\}\right)=\frac{1}{3}\left[\theta_{2} P_{2}^{\alpha}(\phi)-\theta_{2} P_{2}^{\alpha}\left(\left\{g_{2}\right\}\right)\right]
$$

and

$$
\Delta^{\alpha}\left(\left\{g_{1}\right\}\right)=\frac{1}{3}\left[\theta_{3} P_{3}^{\alpha}(\phi)-\theta_{3} P_{3}^{\alpha}\left(\left\{g_{3}\right\}\right)\right]
$$

It is then easy to see that an analyst using only one (arbitrary) permutation of programs in order to assess the performance of each program on poverty reduction would obtain exactly the same results as those provided by the Shapley poverty reduction measure. However, if there exists some overlap between the programs, this result will not hold. Under overlapping programs, if the analyst does not include any other program in the income aggregate when estimating the impact of a given program, he will overestimate the impact of that program. By contrast, if the analyst includes all the other programs in the income aggregate, he will 
underestimate the impact of the program under review. This will be illustrated empirically in section 3 .

The problem encountered in estimating the poverty reduction impact of multiple government programs is also present when measuring the targeting performance of these programs. Assume that the poor represent the target group for the various programs. Then, targeting efficiency is typically analyzed by partitioning the total population in four mutually exclusive groups: the poor who benefit from a program, the poor who do not benefit form the program, the non-poor who benefit from the program, and the non-poor who do not benefit from the program. It is said that an error of inclusion occurs when a non-poor household receives the benefits of a program. An error of exclusion occurs when a poor household does not receive these benefits. In what follows, we use the following four indices to indentify the shares of the population which are, respectively, poor and included (i.e., reached by the program under review), poor and excluded, non-poor and included, and non-poor and excluded:

$$
\begin{aligned}
t_{i}^{1}(S) & :=\frac{\text { poor (according to private income }+ \text { transfers in } S \text { ) and included in program } g_{i}}{\text { total population }} \\
t_{i}^{2}(S) & :=\frac{\text { poor (according to private income }+ \text { transfers in } S \text { ) and excluded from program } g_{i}}{\text { total population }} \\
t_{i}^{3}(S) & :=\frac{\text { non-poor }\left(\text { according to private income }+ \text { transfers in } S \text { ) and included in program } g_{i}\right.}{\text { total population }}
\end{aligned}
$$

and

$t_{i}^{4}(S):=\frac{\text { non-poor (according to private income }+ \text { transfers in } S \text { ) and excluded from program } g_{i}}{\text { total population }}$

Analysts often estimate the above measures of targeting performance using an income 
aggregate which includes all the programs implemented by a government. That is, $S$ is the set of all public policies $G$. As mentioned in the introduction, this is problematic. At the very least, one should exclude the program under review of the income aggregate. A better approach is to adopt measures of targeting performance similar to those proposed above for estimating the poverty reduction impact of programs. There are differences, however, between targeting and poverty reduction. Although the focus axiom could be applied to targeting (e.g., we could say that $t_{i}^{1}(S)$ should be zero if no poor household benefits from program $g_{i}$ ), the additivity axiom cannot because targeting measures are not additive like poverty measures are. Assume for example that we have two programs reaching exactly the same population. Abstracting from the issue of the income aggregate used for measuring targeting performance, the targeting performance measures for both programs taken jointly will be the same as those for each program taken separately, while in the realm of poverty reduction, there should be a gain from implementing two programs rather than one only. Still, the third and most important axiom used for poverty measurement can also be applied to targeting. If we denote by $T_{i}^{l}$ with $l=1,2,3,4$ the targeting measures which we would like to propose in order to take into account the fact that various overlapping government programs are implemented at the same time, these measures should treat equally equivalent policies.

Axiom 5 Equal treatment of equivalent policies (T): If $t_{i}^{l}(S)=t_{j}^{l}(S) \quad \forall S \subseteq N \backslash$ $\left\{g_{i}, g_{j}\right\}$ then $T_{i}^{l}=T_{j}^{l}$ for $l=1,2,3,4$.

Because in the case of targeting we do not have the other two axioms which were used in the case of the poverty reduction impact of programs, we cannot use Shapley's theorem to argue that there is one and only one measure of targeting performance which will have the above property. Bu we can still state the following proposition: 
Proposition 6 One measure of targeting performance which satisfies Axiom 5 is:

$$
T_{i}^{l}=\sum_{s=0}^{n-1} \frac{s !(n-s-1) !}{n !} \sum_{\beta_{-i}(s)} t_{i}^{l}(S),
$$

As for the measurement of the poverty reduction impact of programs, we can compute average measures of targeting performance for policy $g_{i}$ based on all the possible permutations of the various policies implemented by the government. Again, using equation (2) eases a bit the computation of these average measures of targeting performance by allowing the analyst to compute only one time the targeting index for all permutations in which a given policy $g_{i}$ has the same rank and follows the same other policies, whatever the order of those other policies.

\section{Empirical illustration}

We analyze three means-tested programs implemented by the Government of Chile. The data are from the nationally representative 1998 CASEN (Caracterización Socioeconómica Nacional) survey. The three programs are targeted using a common scoring system, the ficha CAS, which is a two page questionnaire filled by households under the supervision of a social worker or técnico-social (welfare assistant). The ficha CAS gathers information on household members (e.g., occupation, education, age, and income) and housing (e.g., housing materials, number and type of rooms, access to water, latrine and sanitary services, etc.) Assets such as housing status, heating equipment, and refrigerator are also taken into account. A household's overall score may vary between 380 and 770 points. Those below 500 points are considered as extremely poor, and those between 500 and 540 points are considered as poor (for more details, see MIDEPLAN 1998 and 1999).

The first program consists of pensions for the elderly or disabled (PASIS, Pensión de Asistencia). To be eligible in 1998, the elderly needed to have an income below half the 
minimum pension allowance (i.e., half of CP $\$ 23,415$ per month; $\mathrm{CP} \$=$ Chilean Pesos). The eligibility threshold is the amount of the PASIS allowance, but beneficiaries are also eligible for free health care. The second program consists of family allowances (SUF, Subsidio Unico Familiar). In 1998, a child above three years of age received CP $\$ 2,500$ per month. A child below three years received $\mathrm{CP} \$ 2,800$. Maternal benefits (CP $\$ 2,800$ per month) are also provided for ten months, as of the fifth month of pregnancy. The third program provides subsidies for water up to a consumption level of 15 cubic meters per month. The rate of subsidy varies from 20 percent to 85 percent of the bill, with a sophisticated system of allowances for each region.

Table 1 gives the impact of the programs on the $P^{\alpha}$ poverty measures. Because the average outlay per household for pension assistance in the sample as a whole (CP\$2078) is larger for means-tested pensions than for family allowances (CP\$ 874) and water subsidies (CP\$210), the impact on poverty is also larger for pension assistance. Interestingly, the impact of family allowances on the headcount is much lower for poverty than extreme poverty, suggesting that those benefiting from these transfers are well below the moderate poverty line (the same is not observed for the other two programs). Note also that for the three programs, the impact on the squared poverty gap is larger with the moderate poverty line.

Rather than commenting upon the impact of the different programs on the various poverty measures, our main interest here is to answer the following question: is there a lot of variation in the estimation of program impacts according to the order with which each program is considered when measuring those impacts? To get a feeling for the magnitude of the measurement error which can occur as a result of the inclusion or exclusion of other programs in the income aggregate when measuring the poverty reduction impact of a given program, one can divide the difference between the maximum and minimum impacts by the 
minimum impact. Recall that the maximum impact of each program is obtained when no other program is included in the income aggregate, while the minimum impact is observed when all the other programs are included in the income aggregate. For program $g_{i}$, we get:

$$
(\operatorname{Max}-\text { Min }) / \operatorname{Min}=\frac{\left(\left[P^{\alpha}(\phi)-P^{\alpha}\left(\left\{g_{i}\right\}\right)\right]-\left[P^{\alpha}\left(G \backslash\left\{g_{i}\right\}\right)-P^{\alpha}(G)\right]\right)}{\left[P^{\alpha}\left(G \backslash\left\{g_{i}\right\}\right)-P^{\alpha}(G)\right]}
$$

A ratio of 20 percent would mean that not including any other program in the income aggregate would increase the performance of the program under review by 20 percent, as compared to the estimated poverty reduction obtained when all the other programs are included in the income aggregate. As indicated in Table 1 , in the case of the headcount index of poverty and extreme poverty, the "(Max-Min)/Min" ratio is above 20 percent for one program, namely water subsidies. This is not surprising since this is the program which has the largest overlap with the other programs. While pension assistance and family allowances tend to be targeted to different population groups (the elderly versus the families with small children), water subsidies are accessible in principle to any poor household. Although this is a matter of personal judgment, we would argue that a potential difference of more than 20 percent in the estimation of the poverty reduction impact of water subsidies justifies the use of the Shapley measure for this program.

In Table 2, we give the four measures of targeting performance for the three programs. As for poverty reduction, we computed for each targeting indicator the ratios (maximum value-minimum value)/minimum value. Water subsidies are again, in most instances, the program for which the ratio is the largest. As mentioned in the introduction, one summary measure of the targeting performance of a program is its targeting/leakage ratio, that is the ratio of the number of poor beneficiaries to the number of non-poor beneficiaries:

$$
t l_{i}=\frac{t_{i}^{1}(S)}{t_{i}^{3}(S)}
$$


Analysts consider an increase in $t l_{i}$ as desirable and a decrease as non-desirable. It can be computed for water subsidies from table 2 that the ratio (maximum value-minimum value)/minimum value for this combined indicator reaches 19.5 percent in the case of extreme poverty, and 7.9 percent in the case of poverty, which is again substantial. More generally, whether one is interested in assessing the poverty reduction impact of programs or their targeting performance, the use of the Shapley measure will be more important if there are many programs under implementation, if these programs are large, and if they overlap in terms of beneficiaries.

\section{REFERENCES}

Baker, J. and M. Grosh, 1994, Poverty reduction using geographic targeting: How well does it work?, World Development, 22, 983-95.

Cornia, G.A. and F. Stewart, 1995, Two errors of targeting, in Van de Walle, D. and K. Nead (ed.), Public Spending and the Poor: Theory and Evidence, John Hopkins University Press, Baltimore.

Foster, J., J. Greer and E. Thorbecke (1984), A Class of Decomposable Poverty Measures, Econometrica, 52, 761-776.

MIDEPLAN, 1999, Estudio del factor discriminatorio de la ficha CAS. Propuesta del mejoramiento del cálculo de puntaje, Santiago de Chile.

MIDEPLAN, 1998, Programas y Subsidios Sociales de Gobierno Priorizados Mediante Ficha CAS-2, Santiago de Chile.

Makdissi, P. and Y. Therrien (2001), Evaluating the Impact of Multiple Public Policies on Poverty, mimeo, Université de Sherbrooke.

Morris, S., C. E. Levin, M. Armar-Klemesu, D. Maxwell, and T. Ruel (1999), Does geographic targeting of nutrition interventions make sense in cities? Evidence from Abidjan and Accra, World Development, 27, 2011-2019.

Shapley, L.S. (1954), A Value for n-Person Games, in H.W. Kuhn and W. Tucker (eds.), Contributions to the Theory of Games II, Annals of Mathematical Studies, 28, Princeton University Press, Princeton.

Wodon, Q. (1997), Targeting the Poor Using ROC Curves, World Development, 25, 2083-2092. 
Table 1: Reduction in poverty and extreme poverty from CAS-targeted programs, Chile 1998

\begin{tabular}{|c|c|c|c|c|c|c|}
\hline & \multicolumn{3}{|c|}{ Extreme poverty } & \multicolumn{3}{|c|}{ Poverty } \\
\hline & Pensions & Family all. & Water subsidies & Pensions & Family all. & Water subsidies \\
\hline & \multicolumn{6}{|c|}{ Reduction in headcount due to the program } \\
\hline Order 123 & 0.860 & 0.426 & 0.047 & 0.707 & 0.133 & 0.073 \\
\hline Order 132 & 0.860 & 0.416 & 0.056 & 0.707 & 0.125 & 0.082 \\
\hline Order 213 & 0.886 & 0.399 & 0.047 & 0.696 & 0.144 & 0.073 \\
\hline Order 231 & 0.876 & 0.399 & 0.058 & 0.703 & 0.144 & 0.067 \\
\hline Order 321 & 0.876 & 0.399 & 0.057 & 0.703 & 0.123 & 0.088 \\
\hline Order 312 & 0.859 & 0.416 & 0.057 & 0.701 & 0.125 & 0.088 \\
\hline (Max-Min)/Min & $3.143 \%$ & $6.767 \%$ & $23.404 \%$ & $1.580 \%$ & $17.073 \%$ & $31.343 \%$ \\
\hline \multirow[t]{2}{*}{ Shapley } & 0.869 & 0.409 & 0.054 & 0.703 & 0.132 & 0.079 \\
\hline & \multicolumn{6}{|c|}{ Reduction in poverty gap due to the program } \\
\hline Order 123 & 0.677 & 0.291 & 0.028 & 0.742 & 0.284 & 0.047 \\
\hline Order 132 & 0.677 & 0.290 & 0.029 & 0.742 & 0.284 & 0.047 \\
\hline Order 213 & 0.660 & 0.307 & 0.028 & 0.740 & 0.286 & 0.047 \\
\hline Order 231 & 0.658 & 0.307 & 0.030 & 0.739 & 0.286 & 0.049 \\
\hline Order 321 & 0.658 & 0.306 & 0.031 & 0.739 & 0.285 & 0.049 \\
\hline Order 312 & 0.675 & 0.290 & 0.031 & 0.740 & 0.284 & 0.049 \\
\hline (Max-Min)/Min & $2.888 \%$ & $5.862 \%$ & $10.714 \%$ & $0.406 \%$ & $0.704 \%$ & $4.255 \%$ \\
\hline \multirow[t]{2}{*}{ Shapley } & 0.667 & 0.298 & 0.029 & 0.740 & 0.285 & 0.048 \\
\hline & \multicolumn{6}{|c|}{ Reduction in squared poverty gap due to the program } \\
\hline Order 123 & 0.599 & 0.235 & 0.019 & 0.712 & 0.293 & 0.038 \\
\hline Order 132 & 0.599 & 0.233 & 0.020 & 0.712 & 0.293 & 0.038 \\
\hline Order 213 & 0.570 & 0.264 & 0.019 & 0.703 & 0.303 & 0.038 \\
\hline Order 231 & 0.566 & 0.264 & 0.023 & 0.700 & 0.303 & 0.040 \\
\hline Order 321 & 0.566 & 0.262 & 0.024 & 0.700 & 0.303 & 0.041 \\
\hline Order 312 & 0.595 & 0.233 & 0.024 & 0.710 & 0.293 & 0.041 \\
\hline (Max-Min)/Min & $5.830 \%$ & $13.305 \%$ & $26.316 \%$ & $1.714 \%$ & $3.413 \%$ & $7.895 \%$ \\
\hline Shapley & 0.582 & 0.248 & 0.021 & 0.706 & 0.298 & 0.039 \\
\hline
\end{tabular}

Source: Authors' estimation from 1998 CASEN survey. 
Table 2: Beneficiaries of CAS-targeted programs, Chile 1998

\begin{tabular}{|c|c|c|c|c|c|c|}
\hline & \multicolumn{3}{|c|}{ Extreme poverty line } & \multicolumn{3}{|c|}{ Moderate poverty line } \\
\hline & Pensions & Family all. & Water subsidies & Pensions & Family all. & Water subsidies \\
\hline & \multicolumn{6}{|c|}{ Poor and included as a share of total population (1) } \\
\hline Order 123 & 1.906 & 3.873 & 0.917 & 4.171 & 8.640 & 3.367 \\
\hline Order 132 & 1.906 & 3.855 & 0.989 & 4.171 & 8.625 & 3.382 \\
\hline Order 213 & 1.852 & 4.130 & 0.917 & 4.151 & 8.727 & 3.367 \\
\hline Order 231 & 1.839 & 4.130 & 0.979 & 4.150 & 8.727 & 3.464 \\
\hline Order 321 & 1.839 & 4.111 & 1.067 & 4.150 & 8.703 & 3.489 \\
\hline Order 312 & 1.905 & 3.855 & 1.067 & 4.159 & 8.625 & 3.489 \\
\hline$(\operatorname{Max}-\operatorname{Min}) / \operatorname{Min}$ & $3.666 \%$ & $7.124 \%$ & $16.291 \%$ & $0.494 \%$ & $1.190 \%$ & $3.608 \%$ \\
\hline \multirow[t]{2}{*}{ Shapley } & 1.874 & 3.992 & 0.989 & 4.158 & 8.674 & 3.426 \\
\hline & \multicolumn{6}{|c|}{ Poor and excluded as a share of total population (2) } \\
\hline Order 123 & 7.832 & 5.005 & 7.535 & 29.822 & 24.646 & 29.786 \\
\hline Order 132 & 7.832 & 4.967 & 7.889 & 29.822 & 24.580 & 29.904 \\
\hline Order 213 & 7.487 & 5.608 & 7.535 & 29.698 & 25.266 & 29.786 \\
\hline Order 231 & 7.443 & 5.608 & 8.360 & 29.632 & 25.266 & 30.385 \\
\hline Order 321 & 7.443 & 5.570 & 8.671 & 29.632 & 25.202 & 30.504 \\
\hline Order 312 & 7.776 & 4.967 & 8.671 & 29.746 & 24.580 & 30.504 \\
\hline (Max-Min)/Min & $5.227 \%$ & $12.903 \%$ & $15.074 \%$ & $0.642 \%$ & $2.792 \%$ & $2.412 \%$ \\
\hline \multirow[t]{2}{*}{ Shapley } & 7.635 & 5.288 & \begin{tabular}{l|l}
8.110 \\
\end{tabular} & 29.726 & 24.923 & 30.145 \\
\hline & \multicolumn{6}{|c|}{ Non-poor and included as a share of total population (3) } \\
\hline Order 123 & 4.178 & 7.584 & 5.493 & 1.914 & 2.817 & 3.043 \\
\hline Order 132 & 4.178 & 7.602 & 5.421 & 1.914 & 2.832 & 3.028 \\
\hline Order 213 & 4.232 & 7.327 & 5.493 & 1.934 & 2.729 & 3.043 \\
\hline Order 231 & 4.246 & 7.327 & 5.431 & 1.934 & 2.729 & 2.946 \\
\hline Order 321 & 4.246 & 7.346 & 5.343 & 1.934 & 2.754 & 2.921 \\
\hline Order 312 & 4.180 & 7.602 & 5.343 & 1.926 & 2.832 & 2.921 \\
\hline (Max-Min)/Min & $1.613 \%$ & $3.748 \%$ & $2.797 \%$ & $1.071 \%$ & $3.761 \%$ & $4.159 \%$ \\
\hline \multirow[t]{2}{*}{ Shapley } & 4.210 & 7.464 & 5.421 & 1.926 & 2.782 & 2.984 \\
\hline & \multicolumn{6}{|c|}{ Non-poor and excluded as a share of total population (4) } \\
\hline Order 123 & 86.084 & 83.538 & 86.055 & 64.093 & 63.898 & 63.804 \\
\hline Order 132 & 86.084 & 83.576 & 85.701 & 64.093 & 63.964 & 63.686 \\
\hline Order 213 & 86.429 & 82.935 & 86.055 & 64.218 & 63.278 & 63.804 \\
\hline Order 231 & 86.473 & 82.935 & 85.230 & 64.283 & 63.278 & 63.205 \\
\hline Order 321 & 86.473 & 82.973 & 84.919 & 64.283 & 63.341 & 63.086 \\
\hline Order 312 & 86.139 & 83.576 & 84.919 & 64.169 & 63.964 & 63.086 \\
\hline (Max-Min)/Min & $0.452 \%$ & $0.773 \%$ & $1.338 \%$ & $0.297 \%$ & $1.084 \%$ & $1.139 \%$ \\
\hline Shapley & 86.280 & 83.256 & 85.480 & 64.190 & 63.620 & 63.445 \\
\hline
\end{tabular}

Source: Authors' estimation from 1998 CASEN survey. Note: $(1)+(2)+(3)+(4)=100$ percent. 
91-01 HANEL, Petr, Standards in International Trade. A Canadian Perspective. (Paru dans Revue Canadienne des Sciences de l'Administration - Canadian Journal of Administrative Sciences, vol. 10.1, Mars 1993).

91-02 FORTIN, Mario, La réforme de l'impôt sur le revenu des particuliers: A-t-on vraiment abaissé les taux d'imposition?

91-03 ASCAH, Louis, Attribution of Pension Fund Surpluses: An Economic Perspective. (Published by Canadian Centre for Policy Alternatives, Ottawa).

91-04 ASCAH, Louis, Attribution du surplus d'un régime de retraite - un regard économique. (Publié par Centre canadien de recherche en politiques de rechange, Ottawa).

91-05 ASCAH, Louis, Recent Federal and Provincial Private Pension Plan Reform Legislation: Missing, Misleading and Shrinking Proposals (Published by Canadian Centre for Policy Alternatives, Ottawa). ASCAH, Louis, La comptabilité des déficits publics : des illusions à la réalité. ALLIE, E., R. DAUPHIN et M. FORTIN, Les aspirations de fertilité des étudiants de l'Université de Sherbrooke. HANEL, PETR, The Liberalization of International Trade in Czechoslovakia, Hungary, and Poland. (Paru dans Comparative Economic Studies, vol. 34, no 3-4, Fall-Winter 1992. ASCAH, Louis, Public Pension Theory for the Real World. FORTIN, Mario, L'écart des taux de chômage canadien et américain. BILODEAU, Marc et AI SLIVINSKI, Rational Nonprofit Entrepreneurship. FORTIN, Mario, The Impact of Unemployment Insurance on the Unemployment Rate. GENTZOGLANIS, Anastassios, Innovation and Competition in the High - and Medium - Intensity R\&D Industries.

93-05 FORTIN, Mario et A. ABDELKRIM, Sectoral Shifts, Stock Market Dispersion and Unemployment in Canada. (Paru dans Applied Economics, volume 29, pp. 829-839, juin 1997.)

93-06 HANEL, Petr, Interindustry Flows of Technology: An Analysis of the Canadian Patent Matrix and Input-Output Matrix for 1978-1989. (Paru dans Technovation, vol 14, no. 8, October 1994.

94-01 BILODEAU, Marc et AI SLIVINSKI, Toilet Cleaning and Department Chairing: Volunteering a Public Service. (À paraître dans Journal of Public Economics)

94-02 ASCAH, Louis, Recent Retirement Income System Reform: Employer Plans, Public Plans and Tax Assisted Savings.

94-03 BILODEAU, M. et AI SLIVINSKI, Volunteering Nonprofit Entrepreneurial Services. (À paraître dans $\underline{\text { Journal of }}$ Economic Behavior and Organization)

94-04 HANEL, Petr, R\&D, Inter-Industry and International Spillovers of Technology and the Total Factor Productivity Growth of Manufacturing Industries in Canada, 1974-1989.

94-05 KALULUMIA, Pene et Denis BOLDUC, Generalized Mixed Estimator for Nonlinear Models: A Maximum Likelihood Approach.

95-01 FORTIN, Mario et Patrice Langevin, L'efficacité du marché boursier face à la politique monétaire.

95-02 HANEL, Petr et Patrice Kayembe YATSHIBI, Analyse de la performance à exporter des industries manufacturières du Québec 1988.

95-03 HANEL, Petr, The Czech Republic: Evolution and Structure of Foreign Trade in Industrial Goods in the Transition Period, 1989-1994. (Paru dans The Vienna Institute Monthly Report, numéro 7, juillet 1995)

95-04 KALULUMIA, Pene et Bernard DÉCALUWÉ, Surévaluation, ajustement et compétitivité externe : le cas des pays membres de la zone franc CFA.

95-05 LATULIPPE, Jean-Guy, Accès aux marchés des pays en développement.

96-01 ST-PIERRE, Alain et Petr HANEL, Les effets directs et indirects de l'activité de R\&D sur la profitabilité de la firme.

96-02 KALULUMIA, Pene et Alain MBAYA LUKUSA, Impact of budget deficits and international capital flows on money demand: Evidence From Cointegration and Error-Correction Model. 

Study Of Selected Countries In Sub-Saharan Africa.

96-04 PARENT, Daniel, Survol des contributions théoriques et empiriques liées au capital humain (A Survey of Theoretical and Empirical Contributions to Human Capital). (Paru dans L'Actualité économique, volume 72. numéro 3, 1996)

96-05 PARENT, Daniel, Matching Human Capital and the Covariance Structure of Earnings

96-06 PARENT, Daniel, Wages and Mobility : The Impact of Employer-Provided Training. (À paraître dans le Journal of Labor Economics)

97-01 PARENT, Daniel, Industry-Specific Capital and the Wage Profile : Evidence From the NLSY and the PSID.

97-02 PARENT, Daniel, Methods of Pay and Earnings: A Longitudinal Analysis

97-03 PARENT, Daniel, Job Characteristics and the Form of Compensation.

97-04 FORTIN, Mario et Michel BERGERON, Jocelyn DUFORT et Pene KALULUMIA, Measuring The Impact of Swaps on the Interest Rate Risk of Financial Intermediaries Using Accounting Data.

97-05 FORTIN, Mario, André LECLERC et Claude THIVIERGE, Testing For Scale and Scope Effects in Cooperative Banks: The Case of Les Caisses populaires et d'économie Desjardins.

97-06 HANEL, Petr, The Pros and Cons of Central and Eastern Europe Joining the EU

00-01 MAKDISSI, Paul et Jean-Yves DUCLOS, Restricted and Unrestricted Dominance Welfare, Inequality and Poverty Orderings

00-02 HANEL, Petr, John BALDWIN et David SABOURIN, Les déterminants des activités d'innovation dans les entreprises de fabrication canadiennes : le rôle des droits de propriété intellectuelle

00-03 KALULUMIA, Pene, Government Debt, Interest Rates and International Capital Flows: Evidence From Cointegration

00-04 MAKDISSI, Paul et Cyril TÉJÉDO, Problèmes d'appariement et politique de l'emploi

00-05 MAKDISSI, Paul et Quentin WODON, Consumption Dominance Curves: Testing for the Impact of Tax Reforms on Poverty

00-06 FORTIN, Mario et André LECLERC, Demographic Changes and Real Housing Prices in Canada.

00-07 HANEL, Petr et Sofiene ZORGATI, Technology Spillovers and Trade: Empirical Evidence for the G7 Industrial Countries.

01-01 MAKDISSI, Paul et Quentin WODON, Migration, poverty, and housing: welfare comparisons using sequential stochastic dominance. Avril 2001. (23 p)

01-02 HUNG Nguyen Manh et Paul MAKDISSI, Infantile mortality and fertility decisions in a stochastic environment. Mars 2001. (12 p).

01-03 MAKDISSI, Paul et Quentin WODON, Fuel poverty and access to electricity: comparing households when they differ in needs Juin 2001. (19 p)

01-04 MAKDISSI, Paul et Yves GROLEAU, Que pouvons-nous apprendre des profils de pauvreté canadiens ? Juillet 2001. (47 p)

01-05 MAKDISSI, Paul et Quentin WODON, Measuring poverty reduction and targeting performance under multiple government programs Août 2001. (16 p)

01-06 DUCLOS, Jean-Yves et Paul MAKDISSI, Restricted inequality and relative poverty. Août 2001. (31 p)

01-07 TÉJÉDO, Cyril et Michel TRUCHON, Serial cost sharing in multidimensional contexts Septembre 2001. (37 p)

01-08 TÉJÉDO, Cyril, Strategic analysis of the serial cost sharing rule with symmetric cost function. Février 2001. $(25 \mathrm{p})$

02-01 DUCLOS, Jean-Yves, Paul MAKDISSI et Quentin WODON, Socially-efficient tax reforms Janvier 2002. (47p)

* Tous ces cahiers de recherche sont disponibles sur notre site WEB (www.usherb.ca/flsh/eco) ou au Centre de documentation de la FLSH A3-330 (UdeS).

Prière d'adresser vos commentaires ou demandes d'exemplaires d'un cahier de recherche antérieur (1976 à 1990) à monsieur Pene KALULUMIA, coordonnateur des Cahiers de recherche du Département d'économique, Tél : 819) 821-7233 Télécopieur : 819) 8217237 Courriel :pkalulum@courrier.usherb.ca

Comments or requests for copies of previous Working Papers (1976 to 1990) should be made to the Working Papers Coordinator at the Département d'économique, Mr. Pene KALULUMIA. Tel: (819) 821-7233

FAX:819) 821-7237 E-mail: pkalulum@courrier.usherb.ca 